\title{
Discovery of practical production processes for arylsulfur pentafluorides and their higher homologues, bis- and tris(sulfur pentafluorides): Beginning of a new era of "super-trifluoromethyl" arene chemistry and its industry
}

\author{
Teruo Umemoto $§$, Lloyd M. Garrick§ and Norimichi Saito§
}

\section{Full Research Paper}

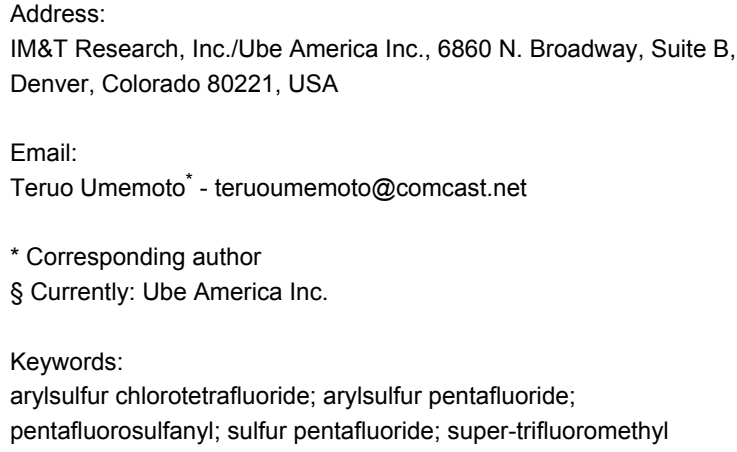

\author{
Beilstein J. Org. Chem. 2012, 8, 461-471. \\ doi:10.3762/bjoc.8.53 \\ Received: 09 November 2011 \\ Accepted: 29 February 2012 \\ Published: 29 March 2012 \\ Associate Editor: D. O'Hagan \\ (C) 2012 Umemoto et al; licensee Beilstein-Institut. \\ License and terms: see end of document.
}

\begin{abstract}
Various arylsulfur pentafluorides, $\mathrm{ArSF}_{5}$, have long been desired in both academic and industrial areas, and $\mathrm{ArSF}_{5}$ compounds have attracted considerable interest in many areas such as medicines, agrochemicals, and other new materials, since the highly stable $\mathrm{SF}_{5}$ group is considered a "super-trifluoromethyl group" due to its significantly higher electronegativity and lipophilicity. This article describes the first practical method for the production of various arylsulfur pentafluorides and their higher homologues, bis- and tris(sulfur pentafluorides), from the corresponding diaryl disulfides or aryl thiols. The method consists of two steps: (Step 1) treatment of a diaryl disulfide or an aryl thiol with chlorine in the presence of an alkali metal fluoride, and (step 2) treatment of the resulting arylsulfur chlorotetrafluoride with a fluoride source, such as $\mathrm{ZnF}_{2}, \mathrm{HF}$, and $\mathrm{Sb}(\mathrm{III} / \mathrm{V}$ ) fluorides. The intermediate arylsulfur chlorotetrafluorides were isolated by distillation or recrystallization and characterized. The aspects of these new reactions are revealed and reaction mechanisms are discussed. As the method offers considerable improvement over previous methods in cost, yield, practicality, applicability, and large-scale production, the new processes described here can be employed as the first practical methods for the economical production of various arylsulfur pentafluorides and their higher homologues, which could then open up a new era of "super-trifluoromethyl" arene chemistry and its applications in many areas.
\end{abstract}

\section{Introduction}

Pentafluorosulfanyl $\left(\mathrm{SF}_{5}\right)$ is considered a "super-trifluoromethyl group" as $\mathrm{SF}_{5}$ has the peculiarity of fluorine beyond a trifluoromethyl $\left(\mathrm{CF}_{3}\right)$ group [1]. Arylsulfur pentafluorides
$\left(\mathrm{ArSF}_{5}\right)$ are very thermally and chemically stable [2]. Pioneering work by Sheppard half a century ago on the synthesis and properties of arylsulfur pentafluorides revealed that 
the $\mathrm{SF}_{5}$ group has absolutely unique properties [2,3]. $\mathrm{SF}_{5}$ is more electronegative (Hammet constants $\sigma_{\mathrm{I}}:+0.55$ for $\mathrm{SF}_{5}$; +0.39 for $\mathrm{CF}_{3}$ ) [2] and more lipophilic than $\mathrm{CF}_{3}$ (Hansch hydrophobicity constants $\pi$ : 1.51 for $\mathrm{SF}_{5} ; 1.09$ for $\mathrm{CF}_{3}$ ) [4]. The high electronegativity results in high polarity in molecules. Thus, it is of significant note that there is no functional group other than $\mathrm{SF}_{5}$ that has both high electronegativity and high lipophilicity, because the two natures are generally in conflict. In addition, $\mathrm{SF}_{5}$ has high hydrolytic stability, which equals or exceeds $\mathrm{CF}_{3}$ [2]. These extraordinary properties render $\mathrm{SF}_{5}$ compounds highly attractive particularly in medicinal [5-14], agrochemical [15-18], and new material [19-23] chemistry and industry. However, there have been no practical, economical methods for the production of arylsulfur pentafluorides. In comparison, trifluoromethyl arenes $\left(\mathrm{ArCF}_{3}\right)$ have grown into a significantly large field in chemistry and industry since their practical two-step production method was developed in the 1930 s through to the 1940 s. The first step was chlorination of $\mathrm{ArCH}_{3}$ to $\mathrm{ArCCl}_{3}$ with $\mathrm{Cl}_{2}$ and the second step was its conversion to $\mathrm{ArCF}_{3}$ with $\mathrm{HF}$ or $\mathrm{SbF}_{3}$ [24-26]. A large number of trifluoromethyl arenes are currently produced on a large scale and used in many areas such as medicines, agrochemicals, dyes, materials for electronics, and others [27-30]. Accordingly, many chemists have long desired to have easy access to the "super-trifluoromethyl" arenes; however, there have been no economical methods for their production until now.

In 1961, Sheppard first reported the synthesis of phenylsulfur pentafluoride by stepwise fluorination of diphenyl disulfide with expensive silver difluorides $\left(\mathrm{AgF}_{2}\right)$ in a fluorocarbon solvent [3]. However, the yield was only $9 \%$. Since then, many substituted phenylsulfur pentafluorides have been prepared by this method, but still with very low yields [3,20,31,32]. In 2000, a new method using molecular fluorine $\left(\mathrm{F}_{2}\right)$ was reported [33]. Thus, bis( $p$ - or $m$-nitrophenyl) disulfide was treated with $\mathrm{F}_{2}$ diluted with nitrogen $\left(\mathrm{F}_{2}: \mathrm{N}_{2}=1: 9 \mathrm{v} / \mathrm{v}\right)$ at low temperature in acetonitrile to give the nitrophenylsulfur pentafluoride in ca. $40 \%$ yield. However, in addition to the low yields, this method requires $F_{2}$, which is a highly toxic, corrosive and explosive gas, and it applies only for the case of electron-deficient nitrophenylsulfur pentafluorides, due to the extremely high reactivity of $F_{2}$. These factors significantly limited the scope and application of this method. Another method reported used expensive xenon difluoride to fluorinate diphenyl disulfide giving phenylsulfur pentafluoride, but its yield was only $25 \%$ [34].

Multiple-step methods have previously been developed for the preparation of arylsulfur pentafluorides. In 1964, it was reported that the reaction of sparsely available and toxic gaseous $\mathrm{SF}_{5} \mathrm{Cl}$ with acetylene, followed by bromination, dehydrobromination, and reduction with zinc, giving pentafluorosulfanylacetylene $\left(\mathrm{HC} \equiv \mathrm{CSF}_{5}\right)$, which was then reacted with butadiene, followed by an aromatization reaction at very high temperature, gave phenylsulfur pentafluoride [35]. Recently, phenylsulfur pentafluoride was prepared by reaction of 1,4-bis(acetoxy)-2-cyclohexene with $\mathrm{SF}_{5} \mathrm{Br}$ under $250 \mathrm{~W}$ sunlamp irradiation, followed by dehydrobromination and then aromatization reactions [36]. A triethylborane-catalyzed reaction of 4,5-dichloro-1-cyclohexene with $\mathrm{SF}_{5} \mathrm{Cl}$ followed by dehydrochlorination has also been reported [37]. The multistep method has recently been extended to the preparation of 2-naphthylsulfur pentafluoride and heteroarylsulfur pentafluorides [22,38-41].

5-Nitrophenyl-1,3-bis(sulfur pentafluoride) was prepared by reaction of the corresponding polymeric disulfide with $\mathrm{AgF}_{2}$ in $12 \%$ yield [3]. Two isomers of phenyl tris(sulfur pentafluorides) were synthesized by many steps starting from the reaction of $\mathrm{SF}_{5} \mathrm{Cl}$ with acetylene via $\mathrm{HC} \equiv \mathrm{CSF}_{5}$ [42]. Complex $\mathrm{Co}(\mathrm{CO})_{4}\left(\mathrm{HC} \equiv \mathrm{CSF}_{5}\right)$ derived from $\mathrm{HC} \equiv \mathrm{CSF}_{5}$ and $\mathrm{Co}_{2}(\mathrm{CO})_{8}$ was decomposed in the presence of $\mathrm{Br}_{2}$ to give phenyl-1,2,4tris(sulfur pentafluoride). Photoreaction of $\mathrm{HC} \equiv \mathrm{CSF}_{5}$ in the presence of $\mathrm{SF}_{5} \mathrm{Cl}$ gave phenyl-1,3,5-tris(sulfur pentafluoride), but in low yield (19\%) [42].

All of the previous methods described above suffer from multiple drawbacks of low yields, the necessity of costly and dangerous fluoro-reagents, and the quite limited scope and applicability. In response to these, we now report practical, inexpensive, and widely applicable methods suitable for the largescale production of arylsulfur pentafluorides and their higher homologues, which have the potential to open up a new era of sulfur pentafluoride chemistry and its industry. These new methods have been described in patents and patent applications [43-48].

\section{Results and Discussion}

Recently we synthesized various arylsulfur trifluorides $\left(\mathrm{ArSF}_{3}\right)$ by treatment of diaryl disulfides with chlorine in the presence of potassium $[49,50]$ or cesium fluoride [50] and thus discovered 4-tert-butyl-2,6-dimethylphenylsulfur trifluoride (Fluolead reagent) as an excellent fluorinating agent with high thermal stability, ease of handling, and wide applicability [50,51]. During the research, we unexpectedly discovered that an arylsulfur chlorotetrafluoride $\left(\mathrm{ArSF}_{4} \mathrm{Cl}\right)$ is formed when a diaryl disulfide is treated with an excess of chlorine in the presence of an excess of the alkaline metal fluoride. Janzen et al. reported that cis- and trans-phenylsulfur chlorotetrafluoride and its $p$-methyl- and $p$-nitro-derivatives were formed by reaction of diaryl disulfide with $\mathrm{XeF}_{2}$ and tetraethylammonium chloride [52]. However, the physical properties of the arylsulfur chlorotetrafluorides were not determined since they were not isolated, 
presumably because the chlorotetrafluorides were considered to be unstable. Instead, their chemical structures were assigned by ${ }^{19} \mathrm{~F}$ - and ${ }^{13} \mathrm{C}$ NMR spectroscopy of the reaction solution.

Arylsulfur chlorotetrafluorides were prepared in high yield by the reactions of diaryl disulfides with an excess amount of chlorine (ca. $7 \mathrm{~mol}$ or more per mole of the disulfide) in the presence of an excess amount of potassium or cesium fluoride (ca. $16 \mathrm{~mol}$ or more per mole of the disulfide) in dry acetonitrile at ice-bath temperature to room temperature. Although conventionally dried and powdered potassium fluoride can be used satisfactorily, spray-dried potassium fluoride, having a large surface area, is preferable. The normal dry potassium fluoride must be used in greater quantities than the spray-dried potassium fluoride. When the reaction is not taken to completion, the distilled product $\left(\mathrm{ArSF}_{4} \mathrm{Cl}\right)$ is contaminated with its intermediate $\mathrm{ArSF}_{3}$. By this method, many arylsulfur chlorotetrafluorides $\mathbf{2 a - 0}$ having different substituents on the aromatic ring were prepared, as summarized in Scheme 1 and Table 1. The products were trans isomers, except for in the case of polyfluorinated arylsulfur chlorotetrafluorides, which formed a mixture of trans and cis isomers. The products were distilled under reduced pressure or crystallized and then characterized.

Arylsulfur chlorotetrafluorides having an electron-donating alkyl group, such as methyl or tert-butyl, or an electron-withdrawing substituent, such as a halogen atom, a nitro-, or a

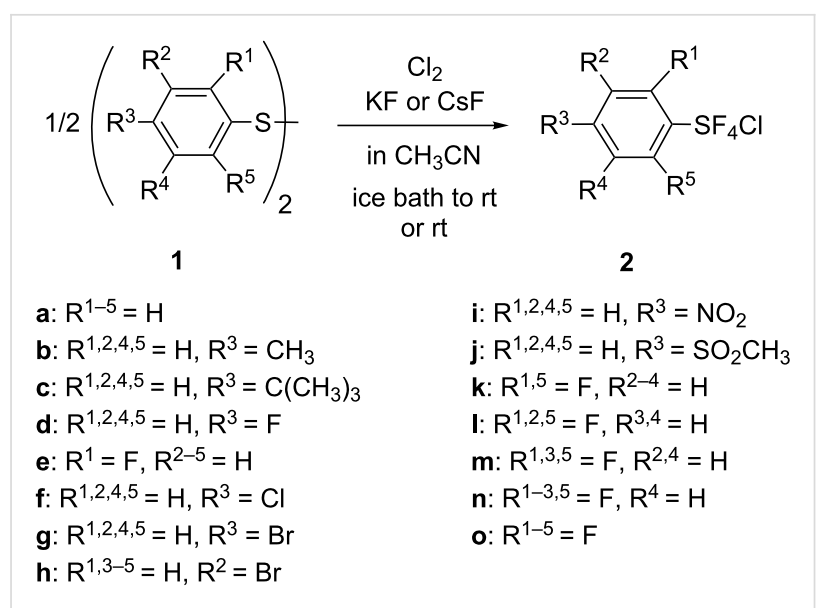

Scheme 1: Preparation of $\mathrm{ArSF}_{4} \mathrm{Cl} 2$.

methanesulfonyl group, were prepared in good to high yields from the corresponding diaryl disulfides. 2-Fluoro and 2,6difluorophenylsulfur chlorotetrafluoride were formed in high yields due to the small steric effect of fluorine atom(s). However, bis(2-bromophenyl) disulfide gave a 11:1 mixture of 2-bromophenylsulfur trifluoride and chlorotetrafluoride. 2-Bromophenylsulfur chlorotetrafluoride was a minor product due to the steric hindrance of the relatively large bromo substituent at the ortho position. Arylsulfur chlorotetrafluorides were also prepared from the corresponding aryl thiols in high yields, as shown in runs 2 and 4, Table 1.

\begin{tabular}{|c|c|c|c|c|c|c|}
\hline run $^{a}$ & $\operatorname{ArSSAr}$ or $\mathrm{ArSH}(\mathrm{mmol})^{\mathrm{b}}$ & $\mathrm{Cl}_{2}^{\mathrm{c}}$ & $\mathrm{MF}^{\mathrm{d}}$ & $\mathrm{ArSF}_{4} \mathrm{Cl}^{\mathrm{e}}$ & conditions $^{f}$ & yield $(\%)^{g}$ \\
\hline 1 & $1 \mathbf{a}(150)$ & $\approx 8$ & $\mathrm{KF}(16)$ & $2 \mathbf{a}(t)$ & ice bath, $9.5 \mathrm{~h}$ & 88 \\
\hline 2 & $\mathrm{C}_{6} \mathrm{H}_{5} \mathrm{SH}(91)$ & 4.9 & $\mathrm{KF}(9)$ & $\mathbf{2 a}(t)$ & $6-10^{\circ} \mathrm{C}, 6.5 \mathrm{~h}$ & 83 \\
\hline 3 & $1 b(500)$ & 7.7 & $\mathrm{KF}(16)$ & $\mathbf{2 b}(t)$ & ice bath, $10.5 \mathrm{~h}$ & 73 \\
\hline 4 & $p-(t-\mathrm{Bu}) \mathrm{C}_{6} \mathrm{H}_{4} \mathrm{SH}(60)$ & 7.5 & CsF (10) & $2 c(t)$ & $5-10^{\circ} \mathrm{C}, 3.5 \mathrm{~h}$ to rt, $24 \mathrm{~h}$ & 84 \\
\hline 5 & $1 d(39)$ & 7.2 & $\mathrm{KF}(16)$ & $2 \mathbf{d}(t)$ & ice bath, $2.5 \mathrm{~h}$ to rt, o.n. & 67 \\
\hline 6 & $1 e(39)$ & 8 & $\mathrm{KF}(16)$ & $2 \mathbf{e}(t)$ & ice bath, $2.5 \mathrm{~h}$ to rt, o.n. & 80 \\
\hline 7 & $1 f(87)$ & 6.6 & $\mathrm{KF}(17)$ & $2 f(t)$ & $5-8^{\circ} \mathrm{C}, 3.5 \mathrm{~h}$ & 88 \\
\hline 8 & $1 \mathrm{~g}(100)$ & 7.2 & $\mathrm{KF}(16)$ & $\mathbf{2 g}(t)$ & ice bath, $4.5 \mathrm{~h}$ to $\mathrm{rt}$, o.n. & 77 \\
\hline 9 & 1h (127) & 6.9 & KF (15.7) & $2 \mathbf{h}(t)$ & ice bath, $5.5 \mathrm{~h}$ to rt, o.n. & 86 \\
\hline 10 & $1 \mathbf{i}(100)$ & 7.2 & $\mathrm{KF}(16)$ & $2 \mathbf{i}(t)$ & ice bath, $4.5 \mathrm{~h}$ to rt, o.n. & 60 \\
\hline 11 & $1 \mathrm{j}(26)$ & 27 & $\mathrm{KF}(40)$ & $2 \mathbf{j}(t)$ & $\mathrm{rt}, 3 \mathrm{~d}$ & $97^{\mathrm{h}}$ \\
\hline 12 & $1 k(100)$ & 10 & $\operatorname{CsF}(18)$ & $2 \mathbf{k}(t / c=92 / 8)$ & ice bath, $5 \mathrm{~h}$ to $\mathrm{rt}, \mathrm{o} . \mathrm{n}$. & 82 \\
\hline 13 & $11(130)$ & 16 & $\mathrm{KF}(22)$ & $2 \mathbf{I}(t / c=89 / 11)$ & ice bath, $6 \mathrm{~h}$ to rt, o.n. & 80 \\
\hline 14 & $1 \mathrm{~m}(77)$ & 16 & $\mathrm{KF}(24)$ & $2 \mathrm{~m}(t / c=96 / 4)$ & ice bath, $6 \mathrm{~h}$ to rt, o.n. & 87 \\
\hline 15 & 1n $(70)$ & 15 & KF (19) & $2 n(t / c=86 / 14)$ & ice bath, $7.5 \mathrm{~h}$ to $\mathrm{rt}$, o.n. & 83 \\
\hline 16 & $10(65)$ & 15 & $\mathrm{KF}(22)$ & $20(t / c=60 / 40)$ & ice bath, $5 \mathrm{~h}$ to rt, o.n. & 86 \\
\hline
\end{tabular}

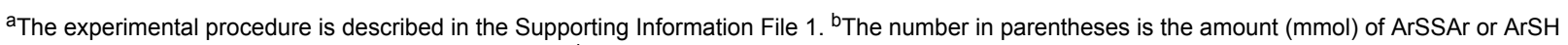
used. "Molar ratio of $\mathrm{Cl}_{2}$ per mole of ArSSAr or ArSH. ${ }^{\mathrm{d}}$ The number in parentheses is molar ratio of MF per mole of ArSSAr or ArSH. ${ }^{e} t=t r a n s-$ isomer, $c=$ cis-isomer. The $t / c$ ratio was determined by ${ }^{19} \mathrm{~F}$ NMR of the reaction mixture before post-treatment. ${ }^{f r t}=$ room temperature, o.n. $=$ overnight. gIsolated yields. ${ }^{\mathrm{h}}$ Crude product. 
The method using aryl thiols as starting materials was successfully applied to the preparation of aryl bis- and tris(sulfur chlorotetrafluorides) as shown in Scheme 2 and Table 2. The method using the corresponding polymeric disulfides did not work well because of their extremely low solubility.<smiles>[R]c1c([R])c([R])c(S)c([R])c1[R]</smiles>

1

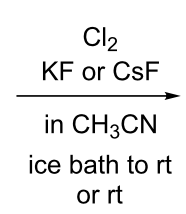

or $\mathrm{rt}$<smiles>[R]c1c([R])c([R])c([Se]Cl)c([R])c1[R]</smiles>

2
Scheme 3 shows a postulated reaction mechanism, which consists of six steps including intermediates 4, 5, 6, 7 and 8 . Treatment of $p$-nitrophenylsulfenyl chloride with $\mathrm{Cl}_{2} / \mathrm{KF}$ gave $p$-nitrophenylsulfur chlorotetrafluoride in $76 \%$ yield. Treatment of phenylsulfur trifluoride with $\mathrm{Cl}_{2} / \mathrm{KF}$ gave phenylsulfur chlorotetrafluoride in $84 \%$ yield. These results support the hypothesis that arylsulfenyl chloride $\mathbf{4}$ and trifluoride 7 are intermediates for the reaction of diaryl disulfide giving arylsulfur chlorotetrafluoride.

In a typical reaction of diphenyl disulfide, an orange color appears immediately as chlorine $\left(\mathrm{Cl}_{2}\right)$ gas is introduced into a mixture of $\mathrm{Ar}_{2} \mathrm{~S}_{2}$ and $\mathrm{KF}$ in acetonitrile. $\mathrm{Cl}_{2}$ is absorbed as fast as it is introduced until $\mathrm{ArSF}_{3} 7$ is formed, at which point the solution becomes colorless. ${ }^{19} \mathrm{~F}$ NMR analysis of the reaction mixture at this moment confirms the formation of 7 . After that, the absorption of $\mathrm{Cl}_{2}$ becomes slow. Thus, the sequence of steps 1 to 4 giving 7 is fast, while the sequence of steps 5 and 6 giving the final product $\mathbf{2}$ is slow. The slow reaction is probably due to an equilibrium reaction (step 5) between 7 and $\mathbf{8}$. The reaction of aryl thiol as a starting material is similar to that of the disulfide 1 since aryl thiol reacts with $\mathrm{Cl}_{2}$ to form disulfide 1.

The arylsulfur chlorotetrafluorides $\mathbf{2 a}-\mathbf{j}$ and bis(sulfur chlorotetrafluorides) $\mathbf{2} \mathbf{p}^{\prime}$ and $\mathbf{2} \mathbf{q}^{\prime}$ obtained were trans-isomers, while

The reaction of a diaryl disulfide with $\mathrm{Cl}_{2}$ and $\mathrm{KF}$ is given as Equation 1 . Per $1 \mathrm{~mol}$ of a diaryl disulfide, $5 \mathrm{~mol}$ of $\mathrm{Cl}_{2}$, and $8 \mathrm{~mol}$ of KF are theoretically consumed.

$$
\mathrm{ArSSAr}+5 \mathrm{Cl}_{2}+8 \mathrm{KF} \rightarrow 2 \mathrm{ArSF}_{4} \mathrm{Cl}+8 \mathrm{KCl}
$$

\begin{tabular}{|c|c|c|c|c|c|c|}
\hline run $^{a}$ & $\operatorname{Ar}(\mathrm{SH})_{n}(\mathrm{mmol})^{\mathrm{b}}$ & $\mathrm{Cl}_{2}^{\mathrm{c}}$ & $\mathrm{KF}^{\mathrm{d}}$ & $\operatorname{Ar}\left(\mathrm{SF}_{4} \mathrm{Cl}\right)_{n}{ }^{\mathrm{e}}$ & conditions $^{f}$ & yield $(\%)^{g}$ \\
\hline 1 & $1 p(68.7)$ & 18 & 25 & $2 \mathbf{p}^{\prime}(t)$ & ice bath, $6 \mathrm{~h}$ to $\mathrm{rt}, 2 \mathrm{~d}$ & 56 \\
\hline 2 & $1 q(64)$ & 20 & 47 & $2 q^{\prime}(t)$ & ice bath, $6 \mathrm{~h}$ to $\mathrm{rt}, 2 \mathrm{~d}$ & 74 \\
\hline 3 & $\operatorname{1r}(80)$ & 23 & 38 & $2 r^{\prime}(t / c=89 / 11)$ & $\mathrm{rt}, 2 \mathrm{~d}$ & $96^{\mathrm{h}}$ \\
\hline 4 & $1 \mathrm{~s}(63)$ & 20 & 20 & $2 s^{\prime}(t / c=95 / 5)$ & ice bath, $7 \mathrm{~h}$ to rt, o.n. & 52 \\
\hline 5 & 1t (64) & 20 & 27 & $\mathbf{2} \mathbf{t}^{\prime}(t / c=58 / 42)$ & ice bath, $7 \mathrm{~h}$ to rt, o.n. & 79 \\
\hline 6 & $1 u(57)$ & 40 & 60 & $2 \mathbf{u}^{\prime}(t / c=79 / 21)$ & $\mathrm{rt}, 3 \mathrm{~d}$ & $98^{\mathrm{h}}$ \\
\hline
\end{tabular}

aThe experimental procedure is described in the Supporting Information File 1. ${ }^{\mathrm{b}}$ The number in parentheses is the amount (mmol) of $\mathrm{Ar}(\mathrm{SH})_{n}$ used. ${ }^{c}$ Molar ratio of $\mathrm{Cl}_{2}$ per mole of $\mathrm{Ar}(\mathrm{SH})_{n}$. ${ }^{\mathrm{d}}$ Molar ratio of $\mathrm{KF}$ per mole of $\mathrm{Ar}(\mathrm{SH})_{n} .{ }^{\mathrm{e}} t=$ trans-configuration, $c=$ cis-configuration. The $t / c$ ratio was determined by ${ }^{19} \mathrm{~F}$ NMR of the reaction mixture or crude product. ${ }^{\mathrm{r}} \mathrm{rt}=$ room temperature, o.n. = overnight. ${ }^{g}$ Isolated yields. ${ }^{h} \mathrm{Crude}$ product.

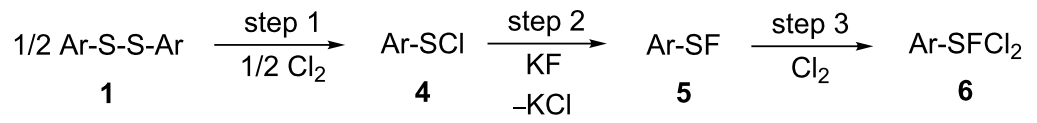

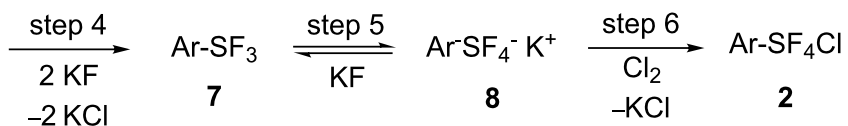


the polyfluorinated $2 \mathbf{k}-\mathbf{o}$, bromo and polyfluoro bis(sulfur chlorotetrafluorides) $\mathbf{2} \mathbf{r}^{\prime}-\mathbf{t}^{\prime}$, and tris(sulfur chlorotetrafluoride) $\mathbf{2} \mathbf{u}^{\prime}$ were a mixture of trans- and cis-configuration. Since we did not observe any isomerization at room temperature or upon distillation, it is reasonable to conclude that each isomer was formed through each isomeric salt of $\mathbf{8}$ as shown in Scheme 4. The multifluoro derivatives $\mathbf{2 0}$ and $\mathbf{2} \mathbf{t}^{\prime}$ have the highest ratio of cis-configuration. This suggests that the relative stability of the cis-isomeric salts 8 increases particularly with increased fluorine substitution. The high ratio of cis-configuration of $\mathbf{2} \mathbf{u}^{\prime}$ suggests the ability of electron-withdrawing groups, such as $-\mathrm{SF}_{4} \mathrm{Cl}$, to stabilize the cis-configuration salt form.

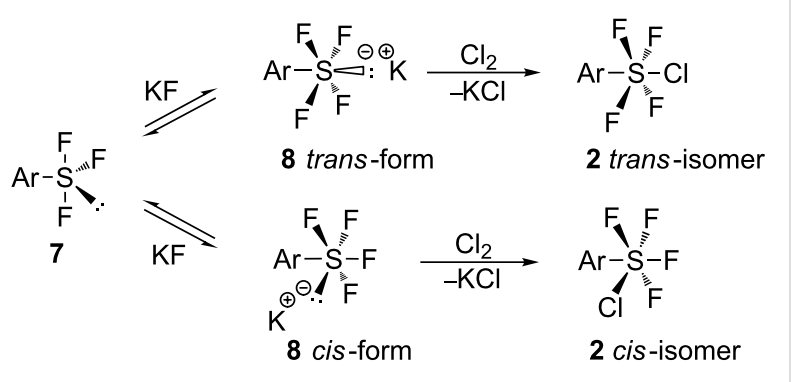

Scheme 4: Reaction mechanism for the formation of trans and cis$\mathrm{ArSF}_{4} \mathrm{Cl}$.

It is noticeable that, except for the polyfluorinated compounds and others discussed above, trans-isomeric $\mathrm{ArSF}_{4} \mathrm{Cl}$ was exclusively formed by the reactions of $\mathrm{Ar}_{2} \mathrm{~S}_{2}$ with $\mathrm{Cl}_{2} / \mathrm{KF}$, while the reactions of $\mathrm{Ar}_{2} \mathrm{~S}_{2}$ with $\mathrm{XeF}_{2} / \mathrm{Et}_{4} \mathrm{NCl}$ gave a mixture of cis- and trans-isomers according to Janzen's report [52]. Janzen proposed radical reactions with $\mathrm{Cl}^{\circ}$ species [52]. The $\mathrm{Cl}_{2} / \mathrm{KF}$ reactions are ionic in nature, in which trans-form salts $\mathbf{8}$ exclusively form and react with $\mathrm{Cl}_{2}$ to give the trans-isomers.

Arylsulfur chlorotetrafluorides are stable during long periods of storage in a fluoropolymer vessel at room temperature. We did not observe any isomerization between trans- and cis-isomers on standing. Whereas arylsulfur trifluorides are extremely sensitive to moisture (water) [50,53], with the exception of the Fluolead reagent [50], arylsulfur chlorotetrafluorides are relatively insensitive to moisture. The half life time of decomposition of phenylsulfur chlorotetrafluoride (2a) in a $\mathrm{CDCl}_{3}$ solution $(\approx 1.2 \mathrm{~mol} / \mathrm{L})$ on direct contact with water was 300 to $500 \mathrm{~min}$ at room temperature. The tracing experiment was conducted with a NMR tube. The ${ }^{19} \mathrm{~F}$ NMR was measured by using an internal standard ( $p$-chlorobenzotrifluoride) and the NMR tube was shaken between the measurements. Gas chromatography (GC) could not be used because of decomposition of arylsulfur chlorotetrafluorides in the GC column. When a few drops of $\mathrm{D}_{2} \mathrm{O}$ were added to a solution of $\mathbf{2 a}$ in $\mathrm{CD}_{3} \mathrm{CN}(1 \mathrm{~mL})$, 2a decomposed in $1 \mathrm{~h}$ and the decomposition product was phenylsulfonyl chloride. Phenylsulfonyl fluoride was detected in a trace amount $(\leq 1 \%)$ by $\mathrm{GC}-$ mass analysis.

Arylsulfur chlorotetrafluorides $\mathbf{2}$ have relatively high thermal stability. Thus, 2a did not decompose during 134 hours at $100{ }^{\circ} \mathrm{C}$ or $48 \mathrm{~h}$ at $150{ }^{\circ} \mathrm{C}$ in a Teflon tube. The isomerization of the trans- to the cis-isomer occurred very slowly. A very small amount (3-4\%) of the cis-isomer was formed after heating of $\mathbf{2 a}$ (trans-isomer) at $150{ }^{\circ} \mathrm{C}$ for $48 \mathrm{~h}$. The real thermal decomposition temperatures of $\mathbf{2}$ could not be determined by a differential scanning calorimeter (DSC), because 2 reacted with the cell materials, i.e., stainless steel and gold, at elevated temperature due to their strongly oxidizing effect on the hexavalent sulfur(VI) element. Many arylsulfur chlorotetrafluorides were measured with DSC and these are discussed in Supporting Information File 1.

We examined reaction conditions for the conversion of trans$\mathrm{PhSF}_{4} \mathrm{Cl}$ (2a) to $\mathrm{PhSF}_{5}$ (3a) with various reactive fluorides using an approximately one-gram scale of $\mathbf{2 a}$, as seen in Table 3. Janzen et al. described in the experimental section that bubbling an excess of $\mathrm{BF}_{3}$ into a mixture of cis- and trans-2a in $\mathrm{CD}_{2} \mathrm{Cl}_{2}$ at $25{ }^{\circ} \mathrm{C}$ led to the gradual disappearance of $\mathbf{2 a}$ and the formation of $\mathrm{PhSF}_{5}$ (3a) [52]. We conducted the reaction of trans-2a (isolated) with $\mathrm{BF}_{3}$ in a sealed reactor and found that all the starting material became a solid residue, probably a polymer (run 1, Table 3). The reaction in dichloromethane solvent resulted in only a $28 \%$ yield of $\mathbf{3 a}$ (run 2). The use of $\mathrm{HBF}_{4} \cdot \mathrm{OEt}_{2}$ at room temperature provided a better yield (40\%) (run 3). A strong Lewis acid $\mathrm{SbF}_{5}$ led to polymeric product, but $\mathrm{SbF}_{3}$ at $80{ }^{\circ} \mathrm{C}$ gave $33 \%$ (run 4). A combination of $\mathrm{SbF}_{3} /$ $\mathrm{SbCl}_{5}$ (cat.) at room temperature provided a better yield (54\%) (run 5). At $80{ }^{\circ} \mathrm{C}$, transition-metal fluorides $\mathrm{TiF}_{4}$ and $\mathrm{CuF}_{2}$ afforded 35 and $57 \%$, respectively (runs 7,8 ). Finally, we found that inexpensive and easily handled $\mathrm{ZnF}_{2}$ produced $\mathbf{3 a}$ in high yield (runs 9, 10).

A ${ }^{19} \mathrm{~F}$ NMR tracing experiment of the conversion reaction of trans- $\mathrm{PhSF}_{4} \mathrm{Cl}$ (trans-2a) provided some information on the reaction mechanism. With $\mathrm{HBF}_{4} \cdot \mathrm{OEt}_{2}$, it was observed that the molar ratio of trans-2a:cis-2a:PhSF 5 was 156:172:100 in the reaction mixture after $7 \mathrm{~h}$, and 3:6:100 after $21 \mathrm{~h}$. With $\mathrm{ZnF}_{2}$, the ratio observed was $22: 117: 100$ during the reaction. A considerable amount of the cis-isomer was formed as an intermediate. It may thus be suggested that there are two routes, a direct route of the trans-isomers to the $\mathrm{SF}_{5}$ products and an indirect route via $c i s$-isomers. The experiment with $\mathrm{HBF}_{4} \cdot \mathrm{OEt}_{2}$ or $\mathrm{ZnF}_{2}$ may be considered to be thermal isomerization of trans-2a to cis-2a with an acid catalyst, suggesting that the cisisomer is more thermodynamically stable than the trans-isomer. 


\begin{tabular}{|c|c|c|c|c|c|c|}
\hline run $^{a}$ & $2 \mathrm{a}(\mathrm{mmol})^{\mathrm{b}}$ & fluoride $(\mathrm{mmol})^{\mathrm{C}}$ & solvent $(\mathrm{mL})^{\mathrm{d}}$ & temperature $\left({ }^{\circ} \mathrm{C}\right)$ & time & yield of $\mathbf{3 a}(\%)^{\mathrm{e}}$ \\
\hline 1 & 4.5 & $\mathrm{BF}_{3}{ }^{\mathrm{f}}$ & none & $\mathrm{rt}$ & $3 d$ & 0 \\
\hline 2 & 6.4 & $\mathrm{BF}_{3}{ }^{f}$ & $\mathrm{CH}_{2} \mathrm{Cl}_{2}(6.4)$ & $\mathrm{rt}$ & $5 \mathrm{~h}$ & 28 \\
\hline 3 & 4.5 & $\mathrm{HBF}_{4} \cdot \mathrm{OEt}_{2}(5.4)$ & $\mathrm{CH}_{2} \mathrm{Cl}_{2}(4.5)$ & $\mathrm{rt}$ & $21 \mathrm{~h}$ & 40 \\
\hline 4 & 4.5 & $\mathrm{SbF}_{3}(2.2)$ & none & 80 & $5 \mathrm{~h}$ & 33 \\
\hline 5 & 4.5 & $\mathrm{SbF}_{3} / \mathrm{SbCl}_{5}$ (2.0/cat.) & hexane (2) & $\mathrm{rt}$ & $3 d$ & 54 \\
\hline 6 & 4.5 & $\mathrm{SnF}_{4}(1.4)$ & none & 80 & $2 \mathrm{~h}$ & 34 \\
\hline 7 & 4.5 & $\mathrm{TiF}_{4}(1.4)$ & none & 80 & $16 \mathrm{~h}$ & 35 \\
\hline 8 & 4.5 & $\mathrm{CuF}_{2}(2.8)$ & none & 80 & $22 \mathrm{~h}$ & 57 \\
\hline 9 & 4.5 & $\mathrm{ZnF}_{2}(2.7)$ & none & 80 & $20 \mathrm{~h}$ & 85 \\
\hline 10 & 4.5 & $\mathrm{ZnF}_{2}(2.7)$ & none & 120 & $4 \mathrm{~h}$ & 88 \\
\hline 11 & 13.6 & $\mathrm{ZnF}_{2} / \mathrm{SbCl}_{5}(8.2 / 1.4)$ & heptane (5) & $\mathrm{rt}$ & $17 \mathrm{~h}$ & 53 \\
\hline
\end{tabular}

${ }^{a}$ The experimental procedure is described in Supporting Information File 1. ${ }^{b}$ The amount $(\mathrm{mmol})$ of $2 \mathrm{a}$ used. ${ }^{\mathrm{c}}$ The number in parentheses is the amount $(\mathrm{mmol})$ of fluoride used. ${ }^{\mathrm{d}}$ The number in parentheses is the amount $(\mathrm{mL})$ of solvent used. ${ }^{e}$ Determined by ${ }^{19} \mathrm{~F}$ NMR. ${ }^{\mathrm{f}}$ See Supporting Information File 1 for the amount of $\mathrm{BF}_{3}$ used.

With $\mathrm{ZnF}_{2} / \mathrm{SbCl}_{5}$ the $c i s$-isomer was barely detected (run 11, Table 3). The ratio of trans-2a:cis-2a:PhSF 5 was 385:0:100 after $10 \mathrm{~min}$; 63 :trace: 100 after $1.5 \mathrm{~h}$; 34:trace:100 after $3 \mathrm{~h}$; and 18:2:100 after $17 \mathrm{~h}$. Thus, the lack of detectable cis-isomer may suggest that the addition of a strong Lewis acid such as $\mathrm{SbCl}_{5}$ gives priority to the direct route. However, we cannot rule out the possibility that the conditions could very quickly convert the cis-isomer to the product.

The method with $\mathrm{ZnF}_{2}$ was applied to $10-50$ gram scale reactions of $\mathrm{PhSF}_{4} \mathrm{Cl}$ (2a) and its derivatives $\mathbf{2} \mathbf{b}, \mathbf{d}, \mathbf{e}-\mathbf{i}, \mathbf{k}$ (Scheme 5). A fluoropolymer reactor charged with the reactants $\left(\mathrm{ArSF}_{4} \mathrm{Cl}\right.$ and $\mathrm{ZnF}_{2}$ ) was heated under the pressure of a balloon filled with $\mathrm{N}_{2}$ gas (no flow of $\mathrm{N}_{2}$ ). The reaction conditions and yields are shown in Table 4. Liquid $\mathbf{2 a , b , d - f , h ~ e f f i c i e n t l y ~ r e a c t e d ~ w i t h ~}$ solid $\mathrm{ZnF}_{2}$ (powder) under stirring without solvent. The two fluorine atoms of $\mathrm{ZnF}_{2}$ were effectively consumed for the reaction. 2a and monohalogenated $\mathbf{2} \mathbf{d}-\mathbf{h}$ were converted to the corresponding products 3 in good to high yields at $120{ }^{\circ} \mathrm{C}$ (bath temperature). It was observed that the start of the exothermic reaction of halogenated $\mathbf{2 f}$ was significantly delayed compared to that of unsubstituted 2a. $p$-Methyl-2b reacted with $\mathrm{ZnF}_{2}$ at $90{ }^{\circ} \mathrm{C}$ (run 2). $p$-Nitro-2i and 2,6-difluoro-2k required a high temperature of $150{ }^{\circ} \mathrm{C}$ or more and their yields were fair to poor (runs 8 and 9). Thus, the electron-donating substituents increase the reactivity of $-\mathrm{SF}_{4} \mathrm{Cl}$, while the electron-withdrawing ones decrease it.

It was found that the product $p$-chloro-3f obtained after distillation (run 5, Table 4) was contaminated (3\%) with $p$-dichlorobenzene (major) and trichlorobenzene (minor), which were formed by cleavage of the $\mathrm{C}-\mathrm{S}$ bond, in the case of the major byproduct, and further chlorination, in the case of the

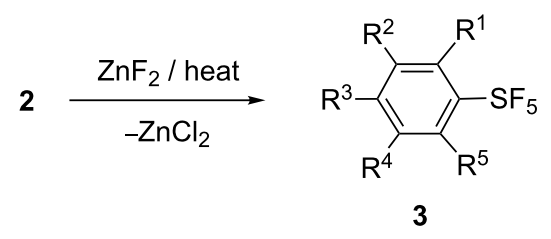
a: $\mathrm{R}^{1-5}=\mathrm{H}$
g: $R^{1,2,4,5}=H, R^{3}=B r$
b: $\mathrm{R}^{1,2,4,5}=\mathrm{H}, \mathrm{R}^{3}=\mathrm{CH}_{3}$
d: $R^{1,2,4,5}=H, R^{3}=F$
h: $R^{1,3-5}=H, R^{2}=B r$
e: $R^{1}=F, R^{2-5}=H$
i: $\mathrm{R}^{1,2,4,5}=\mathrm{H}, \mathrm{R}^{3}=\mathrm{NO}_{2}$
f: $\mathrm{R}^{1,2,4,5}=\mathrm{H}, \mathrm{R}^{3}=\mathrm{Cl}$
k: $R^{1,5}=F, R^{2-4}=H$,

Scheme 5: Preparation of $\mathrm{ArSF}_{5}$ with $\mathrm{ZnF}_{2}$.

minor one, during the reaction. The complete removal of the byproducts from $\mathbf{3 f}$ was difficult due to similar boiling points. We found that the byproducts were suppressed by the addition of a strong Lewis acid $\mathrm{AlCl}_{3}$ and that the addition of $\mathrm{ZnCl}_{2}$ modified the exothermic reaction of $\mathbf{2} \mathbf{f}$ with $\mathrm{ZnF}_{2}$. The addition of $\mathrm{AlCl}_{3}$ decreased the reaction temperature and the addition of $\mathrm{ZnCl}_{2}$ probably helped to form reactive " $\mathrm{ZnFCl}$ " species. Finally the byproduct was restricted to less than $1 \%$ with $\mathrm{ZnF}_{2} /$ $\mathrm{ZnCl}_{2} / \mathrm{AlCl}_{3}$ (molar ratio 100:10:5). The detailed experimental procedure is described in Supporting Information File 1.

The reaction of $\mathrm{PhSF}_{4} \mathrm{Cl}$ (2a) with $\mathrm{ZnF}_{2}$ in Table 4 was conducted under nonflowing $\mathrm{N}_{2}$ gas (under the pressure of a $\mathrm{N}_{2}$ balloon). When the reaction of $\mathbf{2 a}$ was conducted under a flow of $\mathrm{N}_{2}$ gas, the reaction rate became low. We then examined the reaction conditions for $\mathbf{2 a}$ in more detail and found that the reaction was dependent upon the atmosphere of the reaction mixture. While the reaction conducted under a $\mathrm{N}_{2}$ balloon (no flow of $\mathrm{N}_{2}$ ) was completed in $4 \mathrm{~h}$ in $88 \%$ yield, the reaction 


\begin{tabular}{|c|c|c|c|c|c|c|}
\hline run $^{a}$ & $2(\mathrm{mmol})^{\mathrm{b}}$ & solvent & temp $\left({ }^{\circ} \mathrm{C}\right)$ & time (h) & product 3 & yield $(\%)^{c}$ \\
\hline 1 & $2 a(200)$ & none & 120 & 20 & $3 a^{d}$ & 75 \\
\hline 2 & 2b (137) & none & 90 & overnight & $3 b^{e}$ & 71 \\
\hline 3 & $2 \mathbf{d}(42)$ & none & 120 & 16 & $3 d^{f}$ & 62 \\
\hline 4 & $2 \mathrm{e}(42)$ & none & 120 & 15 & $3 e$ & 59 \\
\hline 5 & $2 f(175)$ & none & 120 & 16 & $3 f^{d, g}$ & 73 \\
\hline 6 & $2 \mathbf{g}(100)$ & heptane $(20 \mathrm{~mL})$ & reflux & 17 & $3 g^{d}$ & 79 \\
\hline 7 & $2 h(33)$ & none & 120 & 15 & $3 h^{d}$ & 78 \\
\hline 8 & $2 \mathbf{i}(100)$ & none & 150 & 72 & $3 i^{d}$ & 36 \\
\hline 9 & 2k (160) & none & $130 \rightarrow 180$ & $4 \rightarrow 6$ & $3 k$ & 52 \\
\hline
\end{tabular}

aThe amount of $\mathrm{ZnF}_{2}$ used was $0.6 \mathrm{~mol}$ per $1 \mathrm{~mol}$ of 2 in runs $1-4$ and $6-8,0.53 \mathrm{~mol}$ in run 5 , and 1.06 mol in run 9 . The experimental procedure is

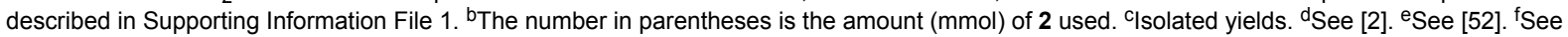
[54]. 9Product $\mathbf{3 f}$ (purity 97\%) obtained after distillation was contaminated with $3 \%$ of $p$-dichlorobenzene (major) and trichlorobenzene (minor). Purity was determined by GC.

conducted under a flow of $\mathrm{N}_{2}$ (through a reactor) was not completed in $5 \mathrm{~h}$ and its yield was down to $67 \%$. With a faster flow of $\mathrm{N}_{2}$, it became slower and the yield decreased. Apparently, a small amount of gas was generated at the beginning of the reaction. The gas was not analyzed because of experimental difficulty. Therefore, it was most likely that removal of the gas by the flow of $\mathrm{N}_{2}$ gas made the reaction slow. Surprisingly, when the reactor was filled with $\mathrm{Cl}_{2}$ gas, the reaction was completed in a short time $(1.7 \mathrm{~h})$ and its yield was very high (92\%). Thus, the presence of $\mathrm{Cl}_{2}$ significantly accelerated the reaction rate and increased the yield. We assumed that one of the effects of the $\mathrm{Cl}_{2}$ atmosphere may be to inhibit a possible disproportionation reaction $\left[2 \mathrm{PhSF}_{4} \mathrm{Cl}(\mathbf{2 a}) \rightarrow \mathrm{PhSF}_{5}+\mathrm{PhSF}_{3}\right.$ $+\mathrm{Cl}_{2} \uparrow$, as the disproportionation leads to the formation of $\mathrm{Cl}_{2}$. Although it remains unclear as to why $\mathrm{Cl}_{2}$ accelerated the reaction, $\mathrm{Cl}_{2}$ may also activate $\mathrm{ZnF}_{2}$ or intermediate " $\mathrm{ZnFCl}$ " species.

Interestingly, this $\mathrm{Cl}_{2}$ atmosphere was effective for the reaction of the $p$-methyl derivative $\mathbf{2 b}$ with $\mathrm{ZnF}_{2}$, but not for the $p$-chloro derivative $\mathbf{2} \mathbf{f}$. The reaction of $\mathbf{2} \mathbf{f}$ with $\mathrm{ZnF}_{2}$ was not affected by $\mathrm{N}_{2}$ flow. As it is known that sulfur-related disproportionation, for instance arylsulfinic acid giving arylsulfonic acid and $S$-aryl arylthiosulfonate ester, is retarded by an electron-withdrawing group [55], it may thus be suggested that an electron-withdrawing substituent limits the disproportionation. Possibly the electron-withdrawing substituent lowers the disproportionation rate or increases the temperature necessary for disproportionation such that it is greater than that required for the replacement reaction of $-\mathrm{SF}_{4} \mathrm{Cl}$ to $-\mathrm{SF}_{5}$.

The method with easily handled and inexpensive $\mathrm{ZnF}_{2}$ under a $\mathrm{Cl}_{2}$ atmosphere was successfully applied to a large-scale production $(\approx 0.5 \mathrm{~kg})$ of $\mathbf{3 a}$ from $\mathbf{2} \mathbf{a}$, in which the addition method was adopted and a small amount of product 3a was used as the reaction solvent. This procedure is described in Supporting Information File 1.

In contrast, anhydrous hydrogen fluoride (HF) is not easy to handle under normal laboratory conditions due to its high toxicity. However, in industry, in addition to its availability as a cheap fluorine source, the gaseous or liquid nature of HF (bp $19{ }^{\circ} \mathrm{C}$ ) is quite suitable for large-scale industrial processes due to its ease in transfer, recovery and recycling.

2a satisfactorily reacted with $\mathrm{HF}$ at less than its boiling point to produce 3a along with the evolution of hydrogen chloride (Scheme 6). As seen in Table 5, this method has successfully been applied to various substituted arylsulfur chlorotetrafluorides. The products obtained by the method were of high purity ( $\geq 99 \%$ ) except for the cases of methyl derivative $\mathbf{2 b}$ (runs 4-6). When the reaction of $\mathbf{2 a}$ was conducted with the addition of $\mathrm{KHF}_{2}(\mathrm{KF}: \mathrm{HF}=1: 1$ ), the yield improved (run 3). KF suppressed the formation of impurities, such as polymeric residue and chlorinated byproducts, because basic KF neutralizes the strong acid $\mathrm{HCl}$ formed in the reaction.

$$
\underset{\mathbf{2 a}}{\mathrm{PhSF}_{4} \mathrm{Cl}+\mathrm{HF}} \frac{15^{\circ} \mathrm{C}}{\text { or less }} \underset{\text { 3a }}{\mathrm{PhSF}_{5}+\mathrm{HCl} \uparrow}
$$

Scheme 6: Preparation of $\mathrm{PhSF}_{5}$ with anhydrous HF.

In run 4 , the purity of product $\mathbf{3 b}$ was $91 \%$, which was contaminated with $8 \%$ of 3-chloro-4-methylphenylsulfur pentafluoride $(\mathbf{3 b} \cdot \mathbf{C l})$ as the main byproduct. Compound $\mathbf{3 b} \cdot \mathbf{C l}$ was tentatively assigned by $\mathrm{GC}$-mass analysis. When the reaction was conducted with the addition of $\mathrm{KHF}_{2}$, the purity greatly 


\begin{tabular}{|c|c|c|c|c|c|c|c|}
\hline run $^{a}$ & $\mathrm{ArSF}_{4} \mathrm{Cl} 2(\mathrm{mmol})^{\mathrm{b}}$ & molar ratio $2 / \mathrm{HF} /$ additive & additive $^{c}$ & temperature $\left({ }^{\circ} \mathrm{C}\right)$ & time $(\mathrm{h})$ & $\operatorname{ArSF}_{5} 3$ & yield $(\%)^{d}$ \\
\hline 1 & $2 a(87.1)$ & 1/29/- & none & 15 & 20 & $3 a$ & 62 \\
\hline 2 & $\mathbf{2 a}(152)$ & 1/24/- & none & -10 & 20 & $3 a$ & 66 \\
\hline 3 & $2 a(96.2)$ & $1 / 25 / 1.1$ & $\mathrm{KHF}_{2}$ & 15 & 18 & $3 a$ & 73 \\
\hline 4 & 2b (144) & $1 / 22 /-$ & none & 15 & 19 & $3 b$ & $73^{\mathrm{e}}$ \\
\hline 5 & 2b (89.8) & $1 / 22 / 1.2$ & $\mathrm{KHF}_{2}$ & 15 & 20 & $3 b$ & $79^{f}$ \\
\hline 6 & $\mathbf{2 b}(80.8)$ & $1 / 30 / 0.37$ & $\mathrm{PhH}$ & 15 & 79 & $3 b$ & $57^{g}$ \\
\hline 7 & 2b (91.8) & $1 / 23 / 1.2 / 0.33^{\mathrm{i}}$ & $\mathrm{KHF}_{2}, \mathrm{PhH}$ & 15 & 17 & $3 b$ & $56^{\mathrm{h}}$ \\
\hline 8 & $\mathbf{2 d}(90.2)$ & 1/28/- & none & 15 & 21 & $3 d$ & 67 \\
\hline 9 & $2 e^{j}(292)$ & 1/23/- & none & 19 & 22 & $3 e$ & $76^{\mathrm{h}}$ \\
\hline 10 & $2 f(146)$ & $1 / 23 /-$ & none & 15 & 20 & $3 f$ & 71 \\
\hline 11 & $\mathbf{2 g}(250)$ & 1/32/- & none & 20 & $2 d$ & $3 g$ & 77 \\
\hline
\end{tabular}

aThe experimental procedure is described in Supporting Information File 1. ${ }^{\mathrm{b}}$ The number in parentheses is the amount $\left(\mathrm{mmol}^{\mathrm{a}}\right.$ ) of 2 used. ${ }^{\mathrm{C}} \mathrm{KHF} \mathrm{F}_{2}=$ potassium hydrogen difluoride. $\mathrm{PhH}=$ benzene. ${ }^{\mathrm{d}}$ Isolated yields after distillation. Purities of the products were $>99 \%$ except for the cases labeled with superscripts e, f, g, h. Purity was determined by GC. ePurity was $91 \%$. fPurity was $97 \%$. gPurity was $90 \%$. hPurity was $99 \%$. 'Molar ratio: $1 / 23 / 1.2 / 0.33$ $=\mathbf{2 b} / \mathrm{HF} / \mathrm{KHF}_{2} / \mathrm{PhH} .{ }^{j} \mathbf{e} \mathbf{e}(71 \mathrm{wt} \%)$ in $\mathrm{CH}_{3} \mathrm{CN}$ was used, which was obtained by concentration (with a vacuum pump) of the filtrate of the reaction mixture after completion of reaction of Scheme 1.

increased to $97 \%$ (run 5). The occurrence of an intermolecular side chlorination reaction was clearly demonstrated by the experiment of run 6 in which benzene was used as an additive. The distilled product $\mathbf{3 b}$ (purity 90\%) was contaminated with $p$-dichlorobenzene $(6 \%)$ and $o$-dichlorobenzene $(3 \%)$ in addition to the byproduct $\mathbf{3 b} \cdot \mathbf{C l}(1 \%)$. The dichlorobenzenes were formed by chlorination of the added benzene. Chlorobenzene formed in this reaction was contained in an initial distillation fraction, which was separated. The method of run 7 using both $\mathrm{KHF}_{2}$ and benzene as additives provided product $\mathbf{3 b}$ with $99 \%$ purity, as the formation of impurity $\mathbf{3} \mathbf{b} \cdot \mathbf{C l}$ was completely suppressed. It is likely that the $\mathrm{SF}_{4} \mathrm{Cl}$ part of $\mathbf{2} \mathbf{b}$ acts as a chlorinating agent toward $\mathbf{3} \mathbf{b}$, or another $\mathbf{2} \mathbf{b}$ and benzene, under the strong acidic conditions that are formed from the $\mathrm{HCl}$ generated in the anhydrous HF.

As seen in runs $8-11$, halogenated arylsulfur pentafluorides 3d-g of high purity ( $\geq 99 \%$ ) were obtained in good isolated yields without any additive. The side reactions such as polymerization and chlorination are restrained, as the aromatic nuclei are deactivated by the electron-withdrawing effect of the halogen atoms.

It was also found that when $\mathrm{PhSF}_{4} \mathrm{Cl}$ (2a) was treated with a $70: 30 \mathrm{w} / \mathrm{w}$ mixture of $\mathrm{HF}$-pyridine at $55{ }^{\circ} \mathrm{C}$, it gave $\mathrm{PhSF}_{5}$ (3a) in $63 \%$ isolated yield (Scheme 7). The HF-pyridine reagent is a nonvolatile and easily handled chemical in the laboratory.

Polyfluorinated arylsulfur chlorotetrafluorides $2 \mathbf{k}-\mathbf{0}$ were smoothly converted to the corresponding sulfur pentafluorides 3k-o in good yields by treatment with a combination of $\mathrm{SbF}_{3}$

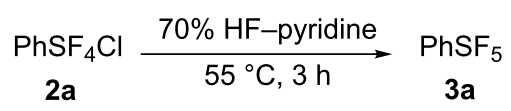

Scheme 7: Preparation of 3a with HF-pyridine.

$$
\begin{aligned}
& 2 \stackrel{\mathrm{SbF}_{3} /}{\mathrm{SbF}_{5}\left(\mathrm{SbCl}_{5}\right)} \longrightarrow \mathrm{R}^{3} \\
& \\
& \text { k: } \mathrm{R}^{1,5}=\mathrm{F}, \mathrm{R}^{2-4}=\mathrm{H} \\
& \text { I: } \mathrm{R}^{1,2,5}=\mathrm{F}, \mathrm{R}^{3,4}=\mathrm{H} \\
& \text { m: } \mathrm{R}^{1,3,5}=\mathrm{F}, \mathrm{R}^{2,4}=\mathrm{H} \\
& \text { n: } \mathrm{R}^{1-3,5}=\mathrm{F}, \mathrm{R}^{4}=\mathrm{H} \\
& \text { o: } \mathrm{R}^{1-5}=\mathrm{F}
\end{aligned}
$$$$
\underbrace{\mathrm{SF}_{5}}_{\mathrm{R}^{5}}
$$

Scheme 8: Preparation of polyfluorinated $\mathrm{ArSF}_{5}$.

and a strong Lewis acid, such as $\mathrm{SbF}_{5}$ or $\mathrm{SbCl}_{5}$, as shown in Scheme 8 and Table 6 .

While treatment of 2,4,6-trifluoro-2 $\mathbf{m}$ with a mixture of $\mathrm{SbF}_{3} /$ $\mathrm{SbF}_{5}(4.5 / 1)$ gave $77 \%$ of product $\mathbf{3 m}$ (run 3, Table 6), treatment of $\mathbf{2 m}$ with $\mathrm{SbF}_{5}$ alone gave a byproduct $(20 \%)$ in addition to $\mathbf{3 m}(60 \%)$. The byproduct was tentatively assigned as 3-chloro-2,4,6-trifluorophenylsulfur pentafluoride by ${ }^{1} \mathrm{H}$ and ${ }^{19} \mathrm{~F}$ NMR and GC-mass analysis. The chlorination as a side reaction may occur from the action of a strong Lewis acid $\mathrm{SbF}_{5}$ on the fluorine atoms of the $\mathrm{SF}_{4} \mathrm{Cl}$ group of $\mathrm{ArSF}_{4} \mathrm{Cl} \mathbf{2 m}$, forming a $\left[\mathrm{ArSF}_{3} \mathrm{Cl}\right]^{+}\left[\mathrm{SbF}_{6}\right]^{-}$species $(\mathrm{Ar}=2,4,6$-trifluoro- 
Table 6: Preparation of polyfluorinated arylsulfur pentafluorides with $\mathrm{Sb}(\mathrm{III}) /(\mathrm{V})$ fluorides.

\begin{tabular}{llllllllll} 
run $^{\mathrm{a}}$ & $\mathbf{2}(\mathrm{mmol})^{\mathrm{b}}$ & $\begin{array}{l}\mathrm{Sb}(\mathrm{III}) \\
\left(\mathrm{mmol}^{\mathrm{c}}\right.\end{array}$ & $\begin{array}{l}\mathrm{Sb}(\mathrm{V}) \\
(\mathrm{mmol})^{\mathrm{c}}\end{array}$ & $\begin{array}{l}\text { molar ratio } \\
\mathrm{Sb}(\mathrm{III}) / \mathrm{Sb}(\mathrm{V})\end{array}$ & solvent $(\mathrm{mL})^{\mathrm{d}}$ & temperature $\left({ }^{\circ} \mathrm{C}\right)$ & time $(\mathrm{h})$ & $\begin{array}{l}\mathbf{3} \\
\text { yield } \\
(\%)^{\mathrm{e}}\end{array}$ \\
\hline 1 & $\mathbf{2 k ( 3 . 9 )}$ & $\mathrm{SbF}_{3}(5.7)$ & $\mathrm{SbCl}_{5}(0.4)$ & $14 / 1$ & $\mathrm{FC}-72(8)$ & $\mathrm{rt}$ & 1 & $\mathbf{3 k}$ & 71 \\
2 & $\mathbf{2 l}(36)$ & $\mathrm{SbF}_{3}(39)$ & $\mathrm{SbF}_{5}(9)$ & $4.3 / 1$ & $\mathrm{FC}-72(40)$ & $-60 \rightarrow \mathrm{rt}$ & 5 & $\mathbf{3 l}$ & 70 \\
3 & $\mathbf{2 m ( 1 0 6 )}$ & $\mathrm{SbF}_{3}(121)$ & $\mathrm{SbF}_{5}(26.7)$ & $4.5 / 1$ & $\mathrm{FC}-72(110)$ & $-60 \rightarrow \mathrm{rt}$ & $\approx 5$ & $\mathbf{3 m}$ & 77 \\
4 & $\mathbf{2 n ( 1 1 8 )}$ & $\mathrm{SbF}_{3}(145)$ & $\mathrm{SbF}_{5}(22.3)$ & $6.5 / 1$ & $\mathrm{FC}-72(200)$ & $\mathrm{rt}$ & 4.5 & $\mathbf{3 n}$ & 61 \\
5 & $\mathbf{2 0}(30.3)$ & $\mathrm{SbF}_{3}(32)$ & $\mathrm{SbF}_{5}(30.4)$ & $1.05 / 1$ & $\mathrm{FC}-72(40)$ & $\mathrm{rt}$ & 1 & $\mathbf{3 0}$ & 71 \\
\hline
\end{tabular}

aThe experimental procedure is described in Supporting Information File 1. ${ }^{\mathrm{b}}$ The number in parentheses is the amount (mmol) of 2 used. ${ }^{\mathrm{c}}$ The number in parentheses is the amount (mmol) of the Sb halide used. ${ }^{\mathrm{d}}$ The number of parentheses is the amount ( $\mathrm{mL}$ ) of the solvent used. FC-72 is a perfluorocarbon with bp $56^{\circ} \mathrm{C}\left(3 \mathrm{M}\right.$ Fluorinert ${ }^{\mathrm{TM}}$ Electronic Liquid FC-72, 3M Specialty Materials, St. Paul, MN, USA). ${ }^{\mathrm{e}}$ Isolated yields.

phenyl), which may act as a strong chlorinating agent $\left(\mathrm{Cl}^{+}\right)$ toward $\mathbf{3 m}$ or another molecule of $\mathbf{2} \mathbf{m}$. Pentafluoro-2o was converted to 30 in good yield with a high molar ratio of $\mathrm{SbF}_{5}$ (run 5) as the reactivity of $\mathbf{2 0}$ was considerably decreased by the five fluorine atoms.

Phenyl bis(sulfur chlorotetrafluorides) $\mathbf{2} \mathbf{p}^{\prime}$ and $\mathbf{2} \mathbf{q}^{\prime}$, bromo derivative $\mathbf{2} \mathbf{r}^{\prime}$, and fluoro derivatives $\mathbf{2} \mathbf{s}^{\prime}$ and $\mathbf{2} \mathbf{t}^{\prime}$ were smoothly converted to the corresponding bis(sulfur pentafluorides) $\mathbf{3 p}$ "-t" in fair to good yields with $\mathrm{SbF}_{5}$ alone, as shown in Scheme 9 and Table 7 (runs 1-5). Phenyl tris(sulfur chlorotetrafluoride) $\mathbf{2} \mathbf{u}^{\prime}$ was converted to phenyl tris(sulfur pentafluoride) $3 \mathbf{u}^{\prime \prime}$ in 55\% yield under similar conditions (run 6, Table 7).

\section{Conclusion}

We have developed the first practical and economical method for the production of various arylsulfur pentafluorides and their higher homologues, which consists of the treatment of diaryl disulfides or aryl thiols with chlorine in the presence of potassium or cesium fluoride, followed by treatment of the resulting arylsulfur chlorotetrafluorides with a fluoride, such as $\mathrm{ZnF}_{2}$, $\mathrm{HF}$, and $\mathrm{Sb}(\mathrm{III} / \mathrm{V})$ fluorides. The important characteristics of these new reactions were revealed and some reactions were modified to provide the products in high purity and in high<smiles>[R]c1c([R])c([R])c([Se]Cl)c([R])c1[R]</smiles>
or $\mathrm{FC}-72 / \mathrm{CH}_{2} \mathrm{Cl}_{2}$

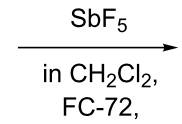<smiles>[R]c1c([R])c([R])c([S-])c([R])c1[R]</smiles>

$p^{\prime}: R^{1,3-5}=H, R^{2}=S F_{4} C l \quad p^{\prime \prime}: R^{1,3-5}=H, R^{2}=S F_{5}$ $q^{\prime}: R^{1,2,4,5}=H, R^{3}=S F_{4} C l \quad q^{\prime \prime}: R^{1,2,4,5}=H, R^{3}=S F_{5}$ $r^{\prime}: R^{1,3,5}=H, R^{2}=S F_{4} C l, R^{4}=B r \quad r^{\prime \prime}: R^{1,3,5}=H, R^{2}=S F_{5}, R^{4}=B r$ $\mathbf{s}^{\prime}: \mathrm{R}^{1,4}=\mathrm{F}, \mathrm{R}^{2,5}=\mathrm{H}, \mathrm{R}^{3}=\mathrm{SF}_{4} \mathrm{Cl} \quad \mathbf{s}^{\prime \prime}: \mathrm{R}^{1,4}=\mathrm{F}, \mathrm{R}^{2,5}=\mathrm{H}, \mathrm{R}^{3}=\mathrm{SF}_{5}$ $\mathbf{t}^{\prime}: \mathrm{R}^{1,2,4,5}=\mathrm{F}, \mathrm{R}^{3}=\mathrm{SF}_{4} \mathrm{Cl} \quad \mathbf{t}^{\prime \prime}: \mathrm{R}^{1,2,4,5}=\mathrm{F}, \mathrm{R}^{3}=\mathrm{SF}_{5}$ $u^{\prime}: R^{1,3,5}=H, R^{2,4}=S F_{4} C l \quad u^{\prime \prime}: R^{1,3,5}=H, R^{2,4}=S_{5}$

Scheme 9: Preparation of aryl bis- and tris(sulfur pentafluorides), $\operatorname{Ar}\left(\mathrm{SF}_{5}\right)_{n}(n=2,3)$.

yields. Since these methods are superior to the previous methods using $\mathrm{AgF}_{2}, \mathrm{~F}_{2}$, or $\mathrm{XeF}_{2}$, or multiple-step methods starting from $\mathrm{SF}_{5} \mathrm{Br}$ or $\mathrm{SF}_{5} \mathrm{Cl}$, in terms of cost, applicability, and scalability of production, the processes developed here can be used as the first practical and economical methods for the production of many kinds of arylsulfur pentafluorides. Thus, it is expected that this will lead to new and rapid advances in "super-trifluoromethyl" arene chemistry and associated industries in many areas.

Table 7: Preparation of aryl bis- and tris(sulfur pentafluorides) with $\mathrm{SbF}_{5}$.

\begin{tabular}{|c|c|c|c|c|c|c|c|}
\hline runa & $2(\mathrm{mmol})^{b}$ & $\mathrm{SbF}_{5}(\mathrm{mmol})^{\mathrm{c}}$ & solvent $(m L)^{d}$ & temperature $\left({ }^{\circ} \mathrm{C}\right)$ & time $(h)^{e}$ & product 3 & yield $(\%)^{f}$ \\
\hline 1 & $2 p^{\prime}(10.8)$ & 21.4 & $\mathrm{CH}_{2} \mathrm{Cl}_{2}(45)$ & $-85 \rightarrow-25$ & 2.5 & $3 p "$ & 57 \\
\hline 2 & $\mathbf{2} \mathbf{q}^{\prime}(11)$ & 24 & $\mathrm{CH}_{2} \mathrm{Cl}_{2}(80)$ & $-85 \rightarrow-15$ & 1.5 & $3 q^{\prime \prime}$ & 71 \\
\hline 3 & $2 \mathbf{r}^{\prime}(77)$ & 130 & $\mathrm{CH}_{2} \mathrm{Cl}_{2}(450)$ & ca. $-85 \rightarrow-15$ & 5 & $3 r^{\prime \prime}$ & 66 \\
\hline 4 & $2 s^{\prime}(27.8)$ & 30.7 & FC-72 (390) & $-80 \rightarrow \mathrm{rt}$, then rt & 8, then o.n. & $3 s^{\prime \prime}$ & 52 \\
\hline 5 & $2 t^{\prime}(12.4)$ & 14.4 & FC-72 (70) & $\mathrm{rt}$ & o.n. & $3 t^{\prime \prime}$ & 67 \\
\hline 6 & $2 \mathbf{u}^{\prime}(32)$ & 99 & $\mathrm{CH}_{2} \mathrm{Cl}_{2} / \mathrm{FC}-72(160 / 68)$ & $-95 \rightarrow+7$ & 6 & $3 u^{\prime \prime}$ & 55 \\
\hline
\end{tabular}

aThe experimental procedure is described in Supporting Information File 1. ${ }^{\text {b}}$ The number in parentheses is the amount (mmol) of 2 used. ${ }^{\mathrm{c}}$ The number is the amount $(\mathrm{mmol})$ of $\mathrm{SbF}_{5}$ used. ${ }^{\mathrm{d}}$ The number in parentheses is the amount $(\mathrm{mL})$ of the solvent used. FC-72 is a perfluorocarbon having bp $56{ }^{\circ} \mathrm{C}\left(3 \mathrm{M}\right.$ Fluorinert ${ }^{\mathrm{TM}}$ Electronic Liquid FC-72, 3M Specialty Materials, St. Paul, MN, USA). ${ }^{\mathrm{O}} \mathrm{o} . \mathrm{n} .{ }^{=}$overnight. ${ }^{\mathrm{f}}$ Isolated yields. 


\section{Supporting Information}

\section{Supporting Information File 1}

Experimental details and copies of ${ }^{1} \mathrm{H}-,{ }^{19} \mathrm{~F}$-, and ${ }^{13} \mathrm{C}$ NMR spectra of new products.

[http://www.beilstein-journals.org/bjoc/content/

supplementary/1860-5397-8-53-S1.pdf]

\section{Acknowledgements}

We thank Ube Industries, Ltd. in Japan for research funding for this work. We thank Drs. Guolin Xu, Axel Klauch-Jacobs, Rajendra P. Singh, and Junichi Chika for some technical contributions.

\section{References}

1. Kirsch, P. Modern Fluoroorganic Chemistry; Wiley-VCH: Weinheim, Germany, 2004; p 151. doi:10.1002/352760393X

2. Sheppard, W. A. J. Am. Chem. Soc. 1962, 84, 3072-3076. doi:10.1021/ja00875a007

3. Sheppard, W. A. J. Am. Chem. Soc. 1962, 84, 3064-3072. doi:10.1021/ja00875a006

4. Hansch, C.; Muir, R. M.; Fujita, T.; Maloney, P. P.; Geiger, F.; Streich, M. J. Am. Chem. Soc. 1963, 85, 2817-2824. doi:10.1021/ja00901a033

5. Stump, B.; Eberle, C.; Schweizer, W. B.; Kaiser, M.; Brun, R.; Krauth-Siegel, R. L.; Lentz, D.; Diederich, F. ChemBioChem 2009, 10 , 79-83. doi:10.1002/cbic.200800565

6. Mo, T.; Mi, X.; Milner, E. E.; Dow, G. S.; Wipf, P. Tetrahedron Lett. 2010, 51, 5137-5140. doi:10.1016/j.tetlet.2010.07.113

7. Gujjar, R.; El Mazouni, F.; White, K. L.; White, J.; Creason, S.; Shackleford, D. M.; Deng, X.; Charman, W. N.; Bathurst, I.; Burrows, J.; Floyd, D. M.; Matthews, D.; Buckner, F. S.; Charman, S. A.; Phillips, M. A.; Rathod, P. K. J. Med. Chem. 2011, 54, 3935-3949. doi:10.1021/jm200265b

8. Coteron, J. M.; Marco, M.; Esquivias, J.; Deng, X.; White, K. L.; White, J.; Koltun, M.; El Mazouni, F.; Kokkonda, S.; Katneni, K.; Bhamidipati, R.; Shackleford, D. M.; Angulo-Barturen, I.; Ferrer, S. B.; Jiménez-Díaz, M. B.; Gamo, F.-J.; Goldsmith, E. J.; Charman, W. N.; Bathurst, I.; Floyd, D.; Matthews, D.; Burrows, J. N.; Rathod, P. K.; Charman, S. A.; Phillips, M. A. J. Med. Chem. 2011, 54, 5540-5561. doi:10.1021/jm200592f

9. Bossemaier, B.; Friebe, W.-G.; Georges, G.; Rueth, M.; Voss, E. Novel pentafluorosulfanyl compounds. U.S. Patent Appl. 0,197,370, Sept 8 , 2005.

10. Andeotti, D.; Checchia, A.; Hamprecht, D.; Micheli, F. 3-triazolylthioalkyl-3-azabicyclo(3.1.0)hexanes and their use as dopamine D3 receptor ligands. WO Patent WO/2006/108700, Oct 19, 2006.

11. Frank, R.; Sundermann, B.; Schick, $H$. Pentafluorosulphanyl-substituted compound and its use for producing medicaments. WO Patent WO/2006/122773, Nov 23, 2006.

12. Billen, D.; Boyle, J.; Critcher, D. J.; Gethin, D. M.; Hall, K. T.; Kyne, G. M. Substituted arylpyrazoles. US Patent Appl. 176,865, July 24, 2008.
13. Kleeman, H.-W. Pentafluorosulfanylphenyl-substituted benzoylguanidines, method for the production thereof, their use as a medicament or diagnostic agent, and a medicament containing these compounds. U.S. Patent 7,446,225, Nov 4, 2008.

14. Stamford, A. W.; Cumming, J. N. Pentafluorosulfurimino heterocyclic compounds as BACE-1 inhibitors, compositions and their use. WO Patent WO/2011/044184, April 11, 2011.

15. Crowley, P. J.; Mitchell, G.; Salmon, R.; Worthington, P. A. Chimia 2004, 58, 138-142.

16. Lim, D. S.; Choi, J. S.; Pak, C. S.; Welch, J. T. J. Pestic. Sci. 2007, 32, 255-259. doi:10.1584/jpestics.G06-50

17. Chern, R. T.; Zingerman, J. R.; Clark, J. N.; Drag, M. D. Sulfurpentafluorophenyl pyrazoles for controlling ectoparasitic infestations. WO Patent WO/1999/047139, Sept 23, 1999.

18. Matsuzaki, Y.; Morimoto, M.; Fujioka, S.; Tohnishi, M. Phtalimide derivative, agricultural or horticultural insecticide, and method of use thereof. WO Patent WO/2003/093228, Nov 13, 2003.

19. Nixon, P. G.; Winter, R.; Castner, D. G.; Holcomb, N. R.; Grainger, D. W.; Gard, G. L. Chem. Mater. 2000, 12, 3108-3112. doi:10.1021/cm000339k

20. Kirsch, P.; Hahn, A. Eur. J. Org. Chem. 2005, 3095-3100. doi:10.1002/ejoc.200500125

21. Gao, H.; Ye, C.; Winter, R. W.; Gard, G. L.; Sitzmann, M. E.; Shreeve, J. M. Eur. J. Inorg. Chem. 2006, 3221-3226. doi:10.1002/ejic.200600098

22. Ye, C.; Gard, G. L.; Winter, R. W.; Syvret, R. G.; Twamley, B.; Shreeve, J. M. Org. Lett. 2007, 9, 3841-3844. doi:10.1021/ol701602a

23. Zahn, S.; Nordquist, A. F.; Minnich, K. E.; Lal, G. S.; Burgoyne, W. F., Jr.; Klauck-Jacobs, A. Pentafluorosulfanyl-substituted thienothiophene monomers and conducting polymers. U.S. Patent 7,060,846, June 13, 2006.

24. Simons, J. H.; Lewis, C. J. J. Am. Chem. Soc. 1938, 60, 492. doi:10.1021/ja01269a507

25. Pouterman, E.; Girardet, A. Helv. Chim. Acta 1947, 30, 107-112. doi:10.1002/hlca.19470300114

26. McBee, E. T.; Hass, H. B.; Weiner, P. E.; Rothrock, G. M.; Burt, W. E.; Robb, R. M.; Van Dyken, A. R. Ind. Eng. Chem. 1947, 39, 298-301. doi:10.1021/ie50447a613

27. Banks, R. E., Ed. Organofluorine Chemicals and Their Industrial Applications; Ellis Horwood Ltd.: Chichester, 1979.

28. Banks, R. E.; Smart, B. E.; Tatlow, J. C., Eds. Organofluorine Chemistry, Principles and Commercial Applications; Plenum Press: New York, 1994.

29. Hiyama, T. In Organofluorine Compounds, Chemsitry and Applications, Yamamoto, H., Ed.; Springer: Heidelberg, Germany, 2000.

30. Kirsch, P. Modern Fluoroorganic Chemistry; Wiley-VCH: Weinheim, Germany, 2004. doi:10.1002/352760393X

31. Sipyagin, A. M.; Bateman, C. P.; Tan, Y.-T.; Thrasher, J. S. J. Fluorine Chem. 2001, 112, 287-295. doi:10.1016/S0022-1139(01)00514-0

32. Sipyagin, A. M.; Enshov, V. S.; Kashtanov, S. A.; Bateman, C. P.; Mullen, B. D.; Tan, Y.-T.; Thrasher, J. S. J. Fluorine Chem. 2004, 125, 1305-1316. doi:10.1016/j.jfluchem.2004.03.008

33. Bowden, R. D.; Comina, P. J.; Greenhall, M. P.; Kariuki, B. M.; Loveday, A.; Philp, D. Tetrahedron 2000, 56, 3399-3408. doi:10.1016/S0040-4020(00)00184-8

34. Ou, X.; Janzen, A. F. J. Fluorine Chem. 2000, 101, 279-283. doi:10.1016/S0022-1139(99)00171-2

35. Hoover, F. W.; Coffman, D. D. J. Org. Chem. 1964, 29, 3567-3570. doi:10.1021/jo01035a030 
36. Winter, R. W.; Gard, G. L. J. Fluorine Chem. 2004, 125, 549-552. doi:10.1016/j.jfluchem.2003.11.028

37. Sergeeva, T. A.; Dolbier, W. R., Jr. Org. Lett. 2004, 6, 2417-2419. doi:10.1021/ol0491991

38. Dolbier, W. R., Jr.; Mitani, A.; Warren, R. D. Tetrahedron Lett. 2007, 48, 1325-1326. doi:10.1016/j.tetlet.2006.12.123

39. Dolbier, W. R., Jr.; Mitani, A.; Xu, W.; Ghiviriga, I. Org. Lett. 2006, 8, 5573-5575. doi:10.1021/ol0622662

40. Dolbier, W. R., Jr.; Zheng, Z. J. Fluorine Chem. 2011, 132, 389-393. doi:10.1016/j.jfluchem.2011.03.017

41. Dolbier, W. R., Jr.; Zheng, Z. J. Org. Chem. 2009, 74, 5626-5628. doi:10.1021/jo9007699

42. Wessel, J.; Hartl, H.; Seppelt, K. Chem. Ber. 1986, 119, 453-463. doi:10.1002/cber.19861190208

43. Umemoto, T. Process for producing arylsulfur pentafluorides. WO Patent WO/2008/118787, Oct 2, 2008.

44. Umemoto, T. Process for producing arylsulfur pentafluorides. U.S. Patent 7,592,491, Sept 22, 2009.

45. Umemoto, T. Process for producing arylsulfur pentafluorides. U.S. Patent 7,820,864, Oct 26, 2010.

46. Umemoto, T. Process for producing arylsulfur pentafluorides. U.S. Patent 7,851,646, Dec 14, 2010.

47. Umemoto, T. Method for producing fluorinated phenylsulfur pentafluorides. U.S. Patent Appl. 2010/0,130,790, May 27, 2010.

48. Umemoto, T. Processes for preparing poly(pentafluorosulfanyl)aromatic compounds. WO Patent WO/2010/033930, March 25, 2010.

49. Pashinnik, V. E.; Martyniuk, E. G.; Tabachuk, M. R.; Shermolovich, Yu. G.; Yagupolskii, L. M. Synth. Commun. 2003, 33, 2505-2509. doi:10.1081/SCC-120021841

50. Umemoto, T.; Singh, R. P.; Xu, Y.; Saito, N. J. Am. Chem. Soc. 2010, 132, 18199-18205. doi:10.1021/ja106343h

51. Xu, W.; Martinez, H.; Dolbier, W. R., Jr. J. Fluorine Chem. 2011, 132, 482-488. doi:10.1016/j.jfluchem.2011.05.001

(Discussing the use of bromine $\left(\mathrm{Br}_{2}\right)$ instead of chlorine $\left(\mathrm{Cl}_{2}\right)$ for the preparation of arylsulfur trifluorides.)

52. Ou, X.; Bernard, G. M.; Janzen, A. F. Can. J. Chem. 1997, 75, 1878-1884. doi:10.1139/v97-621

53. Sheppard, W. A. J. Am. Chem. Soc. 1962, 84, 3058-3063. doi:10.1021/ja00875a005

It was described that the hydrolysis of $\mathrm{PhSF}_{3}$ to benzenesulfinic acid occurs with almost explosive violence.

54. Taft, R. W.; Price, E.; Fox, I. R.; Lewis, I. C.; Anderson, K. K.; Davis, G. T. J. Am. Chem. Soc. 1963, 85, 3146-3155. doi:10.1021/ja00903a022

55. Kice, J. L.; Hampton, D. C.; Fitzgerald, A. J. Org. Chem. 1965, 30, 882-885. doi:10.1021/j001014a053

\section{License and Terms}

This is an Open Access article under the terms of the Creative Commons Attribution License

(http://creativecommons.org/licenses/by/2.0), which permits unrestricted use, distribution, and reproduction in any medium, provided the original work is properly cited.

The license is subject to the Beilstein Journal of Organic Chemistry terms and conditions:

(http://www.beilstein-journals.org/bjoc)

The definitive version of this article is the electronic one which can be found at: doi:10.3762/bjoc. 8.53 